\title{
POSTPRINT
}

Journal of Archaeological Science: Reports 19 (2018) 334-343

https://doi.org/10.1016/j.jasrep.2018.03.007

Received 12 September 2017; Received in revised form 28 February 2018; Accepted 6 March 2018

\section{Early and mid-Holocene coastal settlement and demography in southeastern Norway: Comparing distribution of radiocarbon dates and shoreline-dated sites, 8500-2000 cal. BCE}

Steinar Solheim, Per Persson

Museum of Cultural History, University of Oslo, PB 6762 St. Olavs plass, 0130 Oslo, Norway

Keywords: Southeastern Norway, Demography, Settlement intensity, Coastal regions, Mesolithic

\begin{abstract}
In this paper we explore temporal variation in demography and settlement intensity in southeastern Norway during the Early and mid-Holocene. In order to investigate the temporal variation in demography and settlement we have applied and compared two different proxies: Summed radiocarbon probability distributions and site count data of shoreline-dated sites. The proxies display similar patterns, and we suggest that they indicate stability in settlement in the coastal areas of southeastern Norway between $8500 \mathrm{cal}$. BCE and $2000 \mathrm{cal}$. BCE.
\end{abstract}

\section{Introduction}

The Oslo fjord region of southeastern Norway has unique qualities for studying long-term changes and continuity in coastal settlement during the Holocene. The large and continuous post-glacial land upheaval has caused shore bound sites from all prehistoric periods to be located above the present-day sea level. During the Younger Dryas most of southeastern Norway was covered with ice and the region was not colonised and settled before c. 9300 cal. BCE (Damlien and Solheim, 2017; Glørstad, 2016: 14; Jaksland, 2014: 43-46). A common perception is that the earliest settlement sites were sparse and traces of a highly mobile population (Bjerck, 2009; Jaksland, 2001: 116-118), followed by a growth in population during the Mesolithic reaching a peak in the Late Mesolithic (Jaksland, 2001: 118). This is however not based on thorough investigations of temporal variation of settlement intensity or demography. In this paper we challenge this view by using radiocarbon dates and shoreline-dated sites to investigate variation in demography coastal settlement in southeastern Norway from the Middle Mesolithic to the Late Neolithic periods (8500-2000 cal. BCE; Fig. 1).

During the last decade population dynamics and demographic variation in Mesolithic and Neolithic societies have been thoroughly investigated by using summed radiocarbon probability plots as a population proxy (Apel et al., 2017; Edinborough, 2009; Hinz et al., 2012; Shennan et al., 2013; Shennan and Edinborough, 2007; Timpson et al., 2014). The scopes of the studies are impressive and the methods and models applied to investigate demographic variation are becoming increasingly complex (Edinborough et al., 2017: 1-2 for overview of development; Shennan et al., 2013; Timpson et al., 2014). Basically, reconstructions of prehistoric demography are based on temporal distribution of radiocarbon dates, which are used as a proxy of variation in human activity through time. Several researchers have emphasized the problems of using radiocarbon data alone to infer demographic variation and noted the need for other proxies to compare with the radiocarbon probability plots (Crombé and Robinson, 2014; Hinz et al., 2012; Surovell and Brantingham, 2007; Tallavaara et al., 2010; Torfing, 2015; Williams, 2012; but see Edinborough et al., 2017). 
Both human factors and systematic errors are pointed out as potential biases (Torfing, 2015:193; Williams, 2012:579; c.f. Timpson et al., 2015). One suggested approach to test if variations in radiocarbon plots are related to human activity is to compare radiocarbon plots with paleoenvironmental data, such as pollen analysis or climate data (Hinz et al., 2012; Wicks and Mithen, 2014). A second possible approach for investigating whether a set of radiocarbon dates is biased is by comparing radiocarbon plots and archaeological site counts (French and Collins, 2015; Palmisano et al., 2017; Tallavaara et al., 2010). Following this approach we will compare the available radiocarbon data with other archaeological proxy data in order to study the coastal population and settlement around the Oslo fjord in southeastern Norway. In order to carry out this approach we will use summed radiocarbon probability distribution, and site-counts of shoreline-dated sites from three different subareas in this region.

The main aim is to investigate variation in demography and settlement intensity in the Oslo fjord region from c. 8500 to $2000 \mathrm{cal}$. BCE. This calls for a source critical view of the available radiocarbon data, and the question we ask first is if radiocarbon data from the Oslo fjord region can be used as proxy for variations in human activity or if it is merely a reflection of archaeological activity and/or dating strategies. For this purpose we will 1) investigate the temporal distribution of radiocarbon dates from the Oslo fjord region, and 2) investigate the temporal distribution of shoreline-dated sites from three different subareas in the same region. The summed radiocarbon probability distributions will be compared with the site count data to explorevariations in settlement in the coastal areas.

\section{Background}

\subsection{The Oslo fjord region}

Stone Age research in the Oslo fjord region started around 1900. Chronological and typological studies dominated until the 1970s when ecological aspects came into focus. Settlement patterns have been discussed, especially concerning coast - inland relations (Boaz, 1998; Lindblom, 1984; Mikkelsen, 1978), but studies of temporal variation in settlement intensity during the Stone Age is yet to be the subject of rigorous research. Due to intense infrastructural development in the Oslo fjord region over the last 15 years, this is now changing. A large number of Stone Age sites have been excavated, generating a rich body of data suited for studies of temporal variation in demography and settlement. Sites dating from the Pioneer phase in the Preboreal period throughout the whole Mesolithic and Neolithic have been investigated (Glørstad, 2004; Jaksland and Persson, 2014; Melvold and Persson, 2014; Reitan and Persson, 2014; Solheim, 2017; Solheim and Damlien, 2013).

In addition to high intensity in archaeological excavations, the geological background in the region is of great importance for studying temporal development in human activity. The retreat of the Scandinavian Ice Sheet and the following heavy land uplift caused dramatic changes in the region's landscape (Bergstrøm, 1999). This is most notable early in the Preboreal period where a land uplift of $4-5 \mathrm{~m}$ in 100 years is documented in the western part of the region (Sørensen et al., 2014a). Unlike most parts of Europe, the glacio-isostatic rebound has caused constant land uplift after the Last Glacial maximum, and no Holocene transgressions are documented in the study area (Fig. 2; Sørensen et al., 2014a, 2014b). Consequently we have the opportunity to establish a well-founded relative chronology of sites and also to date sites independent of radiocarbon- or typological/technological dating.

This implies that the Oslo fjord region have qualities compared to only a few other regions in the world for studying long term continuity and changes in coastal settlement during the Holocene (c.f. Bailey, 2011; Edinborough et al., 2017), and also for using Stone Age sites as a proxy for settlement intensity. 


\subsection{Coastal settlement and shorebound Mesolithic sites}

The majority of the excavated sites in the Oslo fjord region are interpreted as shorebound or situated close to the contemporary shoreline (Solheim and Persson, 2016: 265-266). Breivik et al. (2017: 11, Fig. 9), has argued for a close correspondence between Mesolithic sites and contemporary shoreline in southeastern Norway, and have demonstrated a strong association between radiocarbon dated archaeological contexts and changing shorelines.

Mesolithic sites in the region are to a very large degree similar (e.g. Melvold and Persson, 2014; Solheim, 2017, 2017a, 2017b, 2017c). Most sites are open-air dwelling sites with podzolic soils. Preservation conditions are similar at sites from the whole period, and, in general, no complex cultural stratigraphy is present at the open-air sites. Preservation for organic material is poor, and organic material for dating is usually found in preserved remains of structures such as hearths, cooking pits, etc., or in relation to concentration of lithic finds (Solheim, 2017a: 101-102). Several excavated sites do not have radiocarbon dates reflecting human activity from the time when the site was shorebound (Solheim, 2017b: 70). This can be due to a lack of organic material from that phase or it might simply be the case that the site was not used or settled by humans when it was shorebound. The radiocarbon dates also, in some cases, indicate use later in the Mesolithic or in the Bronze and Iron Age (Fossum, 2017). Several explanations, which are related to both natural and cultural causes, can be offered. A number of radiocarbon dates are clearly related to human activity as they are found in structures of anthropogenic origin. Natural processes like bio- and cryoturbation, which induces migration and potential mixing of artifacts and ecofacts is a common source critical factor, and some of the radiocarbon dates might be the result of charcoal left in the ground after for example forest fires and hence polluting Mesolithic structures. When a site's elevation above sea level and technological/typologicaltraits is compared it is however possible to get an impression of whether a site was situated close to the contemporary shoreline or not, even when no radiocarbon dates are available. The typological and technological development is well known in the region and can be used to date the activity phases at the sites (Damlien, 2016; Eigeland, 2015; Reitan, 2016). Based on radiocarbon and technological/typological data from excavations we estimate that approximately $10 \%$ of the Mesolithic sites included here were not shorebound during their time of use (compare Breivik et al., 2017: Fig. 9). Thus we argue that a chronological bias is not a significant problem for using shoreline-dated sites as a proxy for settlement intensity in the Mesolithic. During the Neolithic agriculture was, to a varying degree, a part of the subsistence, and the proportions of sites close to the shore varies accordingly. The possibility to date sites based on elevation above sea level makes it possible to include a large number of Stone Age sites in temporal analysis. Numerous sites have been surveyed and documented by extensive test pitting but the majority of these sites are never excavated and cannot be dated by radiocarbon method, typological or technological traits. These sites are largely ignored in scientific analysis, but as it is possible to date the sites by using the shoreline displacement curves, we believe they represent valuable data, and here we will use these sites as a proxy to evaluate the settlement intensity around the Oslo fjord.

There are some potential problems with using surveyed sites as data: Survey intensity will affect the number of sites and some height intervals can be overrepresented. There seems to be a tendency towards more intensive surveying in the highest lying areas, which is where the oldest sites are located (e.g. Olsen, 2012: 57). In order to test the relative frequency of test pits at different height intervals, we have investigated the number of test pits in relation to the total amount of land at different height intervals in the western part of the study area (Persson, 2014:56-57; Solheim, 2017c: 40-41). This demonstrate that the total number of test pits is quite equal at different height intervals, but it shows that there are relatively more test pits containing lithic finds at lower Late Mesolithic height levels 
(30-60ma.s.1.), compared to the Early and Middle Mesolithic levels (> 60ma.s.1.). This could be cultural historically significant, and related to the larger size of the Late Mesolithic sites and higher amount of lithic artifacts found at these sites compared to earlier Mesolithic sites. Secondly, most surveyed sites are situated in areas affected by infrastructural and other community development, which can lead to geographical and chronological biases in the data set. This is for instance of importance for the number of surveyed Early Mesolithic sites as highways and railways rarely are situated higher than 100ma.s.l. in this region. Finally, the quality of shoreline displacement curves varies and a curve is only valid for a limited area as there is great variation in shoreline displacement between different parts of the Oslo fjord region. The newly developed shoreline curves are more precisely dated than the older curves by using AMS-dating and also a higher number of radiocarbon dates. Nevertheless, we consider the different shoreline displacement curves to be of sufficient quality to perform the present study.

\section{Materials and method}

\subsection{Radiocarbon dates and summed radiocarbon probability distribution}

The radiocarbon data set used in this analysis consists of 512 dates from 157 individual archaeological excavation sites situated around the Oslo fjord (c.f. Fig. 1). All dates are of terrestrial origin and there are no issues with a marine reservoir effect (c.f. Edinborough et al., 2016, 2017). The majority of dates are collected from published literature and excavation reports but some are unpublished. In this paper we use a version of the "UCL-method" (Shennan et al., 2013; Timpson et al., 2014; Edinborough et al., 2017). Such simulationbased models based on real archaeological datasets have shown to be useful for identifying changes related to population fluctuation in archaeological contexts (Edinborough et al., 2017:1; Bevan et al., 2017; see also Timpson et al., 2015). The paper by Edinborough et al. (2017) has also demonstrated the value of this simulation-based method for studying early and mid-Holocene coastal population.

The empirical summed radiocarbon probability distribution (SPD) is compared with sets of simulated SPDs generated by a random sampling of calendar dates from period 8500 to 1500 cal. BCE (Fig. 3). This is equivalent to a comparison with a model that assumes constant production of radiocarbon dates, and unlike the abovementioned studies we assume that the population size and settlement were constant during the entire period in question. The simulated calendar dates were "backcalibrated" to simulate a radiocarbon date. Each back-calibrated date was then added a random standard deviation from the empirical dates, and then calibrated and summed. The procedure was repeated 1000 times, and a mean and a 95\% confidence interval was calculated (see Timpson et al., 2014; Edinborough et al., 2017 for a detailed explanation of the method). This was carried out for all dates (Fig. 3a) and for bins of dates (Fig. 3b) combining dates from each site that is $<200$ radiocarbon years apart into one bin as proposed by Shennan et al. (2013:6). This account for oversampling, and sites with different amount of dates were equally weighted in the analysis. The calibration is performed with the Bchron programme (https://github.com/andrewcparnell/Bchron) and the simulation is performed with a slightly modified version of the "UCL-method" with R software codes published by Edinborough et al. (2017). The calibration use the intcal13 calibration curve (Reimer et al., 2013).

\subsection{Shoreline displacement and dating of Stone Age sites}

In addition to the C14-dates we have gathered information from 1709 surveyed sites from the three different parts of the Oslo fjord region (Fig. 4). Surveyed sites are registered in the Directorate for Cultural Heritage's online database Askeladden (Askeladden, 2015). The database contains information about the sites geographical location thus making it possible to extract information about 
the sites elevation above sea level from a GIS-based Digital terrain model ${ }_{1}$ (kartverket.no). Information about surveyed sites is generated from sub-areas covering the western, eastern as well as the inner parts of the Oslo fjord. Sites are dated according to their elevation above present sea level.

Geoscientists have, often in close cooperation with archaeologists, developed new shoreline displacement curves covering the western and eastern part of our study area (Påsse, 2003; Sørensen, 1999; Sørensen et al., 2014a, 2014b, 2015; c.f. Fig. 2). The curves used in this study are adjusted to Gunnarsrød bog in Telemark for the western part of the Oslo fjord, and to Lake Vaglarna in Bohuslen for the eastern part (Påsse, 2003; Sørensen et al., 2014a). From the northern part of the Oslo fjord region a curve valid for the Ski terminal moraine is used. It was originally constructed in 1979 but has recently been adjusted (Bargel and Sørensen, 2005; Sørensen, 1979). The available shoreline displacement curves for the Oslo fjord region cover the time span from the Preboreal to the present. Water basins situated below marine limit contain bottom sediment layers originating from the time the basin was isolated from the sea. The transition levels between marine and lacustrine sediments, indicating the isolation of the basin, are identified and radiocarbon dated. When this is done for several basins situated at different altitudes it is possible to construct a shoreline displacement curve. This method is called the isolation basin method (Hafsten, 1956) and is the main method used for constructing shoreline curves around the Oslo fjord.

Normally only one basin is investigated from the same geographical location. Consequently, the shoreline curves are constructed from several basins located at different places and the basins' height above sea level needs to be adjusted for differences in land upheaval. The normal procedure used in shoreline displacement studies is to re-calculate the height above sea level of different basins' isolation point, or threshold, to the contemporary shoreline level at one single geographical location - a "nillpoint". As most sites are situated away from the "nill-points" used here, Gunnarsrød bog, Ski and Lake Vaglarna, the sites need to be adjusted to the contemporary height of one of the curves. We have carried out height adjustments in accordance with the method presented by Sørensen et al. (2014a: 4244, Fig. 2.2.9) and Påsse (2003: 48-49, Table 2). At the western side of the Oslo fjord almost all sites included in this study are distributed along the same isobar, i.e. a line with the same land upheaval as Gunnarsrød bog, which means that there is little need for compensation for difference in land upheaval between the archaeological sites. On the eastern side of the fjord, the sites have a wider distribution in north-south direction. The site that deviates the most is Tørkop, Halden, dated to c. 7700 cal. BCE and situated $13 \mathrm{~km}$ from Lake Vaglarna measured perpendicular to isobars. The correction factor is 35 $\mathrm{cm} / \mathrm{km}$ (Påsse, 2003: 48-49, Table 2) and the total correction for Tørkop is a subtraction of $4.6 \mathrm{~m}$ compared to the shoreline curve. Several sites included in this study are situated in the Svinesund area (Glørstad, 2004), and needs a minor adjustment for differences in land upheaval compared to Lake Vaglarna.

In order to adjust for variations in shoreline displacement between the areas, we have estimated the age of all sites in accordance to their local shoreline curve. We have ascribed all sites to 500 years bins for analysing the general trends. Note that sites older than $8500 \mathrm{cal}$. BCE are included in a single bar in the diagrams. The land upheaval is extremely high in the Preboreal period, and it will require a detailed analysis for the different areas at a more local scale to include and shoreline date sites from the period. As there is no radiocarbon dates from archaeological sites dated to the Early Mesolithic in this region (9500-8300 cal. BCE) we focus the further discussion on the period from c. 8500-2000 cal. BCE.

\section{Results and discussion}




\subsection{Summed radiocarbon probability distribution}

The summed radiocarbon probability distribution including all dates from the entire Oslo fjord area (Fig. 3a) shows some distinctive traits: First, there are no dates earlier than c. 8000 cal. BCE. Secondly, the SPD demonstrate three peaks with higher number of dates during 1) the Middle Mesolithic, between c. 7800-7400 cal. BCE, 2) at the transition to the Neolithic, c. 3900-3700 cal. BCE, and 3) in the Late Neolithic, from c. 2000 cal. BCE, which represents the start of a period with high number of radiocarbon dates. The summed radiocarbon probability distribution is within the $95 \%$ confidence interval of the variation of the simulated curves during the entire early and mid-Holocene indicating a relative stable population. At c. $2000 \mathrm{cal}$. BCE the curve rises significantly above the confidence level, indicating a rapid increase in population. We will explore these main results in greater detail below.

The oldest radiocarbon dates from southeastern Norway are from c. 8000 cal. BCE; meaning that it does not exist radiocarbon dates from Early Mesolithic archaeological contexts. The reason for the lack of radiocarbon dates from Early Mesolithic sites is not understood at the moment but a potential explanation might be the type of fuel in the hearths during the earliest phase. It has been suggested that seal oil or blubber was used as fuel (Bjerck, 2016) and for that reason the activity at the sites have not produced sample material, such as charcoal, suitable for radiocarbon dates. This theory is however not very likely as firewood would be accessible already from the time the first pioneer settlers entered the region (Sørensen et al., 2014a), and thus far we have no evidence of the use of seal oil of blubber in Southern Norway (Åstveit, 2014; but see Petterson and Wikell, 2014). Charcoal is also retrieved from archaeological contexts in other parts of Southern Norway and radiocarbon dated to the Early Mesolithic. We hypothesize that the lack of Early Mesolithic radiocarbon dates in our study area is most likely caused by a combination of factors, such as type of hearth, fuel as well as taphonomic processes (Théry-Parisot et al., 2010), which we at this point cannot explain. It is however not likely that the absence of radiocarbon dates from 9500 to 8000 cal. BCE reflects a settlement intensity of $<1 \%$ to that of the later periods. Quite the contrary, it has been stressed that the Early Mesolithic was a period with especially good conditions for settlement in the region which our data and data from neighbouring regions also demonstrate with a very high frequency of recorded Early Mesolithic sites (Breivik, 2014; Schmitt et al., 2006; Solheim, 2017c). In our data c. 10\% of the surveyed sites are shorelinedated to Early Mesolithic, and excavations have also documented extensive traces of activity in this period.

The coastal region of southeastern Norway has a similar cultural historical development and ecological conditions during the Mesolithic, and is considered as a common cultural area (Glørstad, 2010; Solheim and Persson, 2016). There is no reason to assume any significant differences in the general settlement history between different parts of the region. A possible way to test the interpretation of the sum probability distribution is thus by comparing independent sets of radiocarbon dates from different sub-areas. In Fig. 5 we have made a division between radiocarbon dates from the eastern and western parts of the region as well as the inner Oslo fjord. The majority of dates are from the western side of the fjord but we consider the data to be sufficient for comparison of the three subareas. The summed radiocarbon probability distributions from the subareas demonstrate some similar tendencies as the general model; there are no dates before c. $8000 \mathrm{cal}$. BCE, followed by an increase c. $7500 \mathrm{cal}$. BCE, and with a dramatic increase starting at c. 2000 cal. BCE. The Early Neolithic peak starting at c. 3900 cal. BCE is present but not that pronounced in all subareas.

The peak at $7500 \mathrm{cal}$. BCE is most prominent in the distribution plot for the western part of the region (Fig. 5). This is possibly a reflection of excavation intensity and dating strategies connected to sites from the Middle Mesolithic period in this part of southeastern Norway (Solheim, 2013) and possibly 
also by calibration effects (Michczyñski and Michczyñska, 2006). There are many dated sites from this period (Solheim, 2013, 2017a; Melvold and Persson, 2014), and a few sites contain relatively high numbers of radiocarbon dates, e.g. Hovland 3, Larvik, with 18 dates between 7750 and $7180 \mathrm{cal}$. BCE (Solheim and Olsen, 2013). There is a synchronous increase in the curves both for the inner and eastern part of the region at c. $7500 \mathrm{cal}$. BCE, but one should also be careful not to over-interpret this peak due to the lack of dates from the Early Mesolithic.

The peak in the Early Neolithic should also be commented. This increase in dates could be a real effect, directly or indirectly caused by the introduction of agriculture (c.f. Shennan et al., 2013). However about $30 \%$ of the radiocarbon dates between 4000 and 3500 cal. BCE are from the sites Vestgård 6, Halden (eastern part), and Langangen Vestgård 6, Porsgrunn (western part). These sites are, in a southeastern Norwegian measure, well dated and the dating strategy following the excavations was to pinpoint the transition to the Neolithic. It could also be mentioned that $40 \%$ of the radiocarbon dates from the same period come from sites excavated in two excavation projects, both of which had a focus on the process of Neolithisation (Glørstad, 2004; Melvold and Persson, 2014; Reitan and Persson, 2014). The peak in the Early Neolithic might be biased because of dating strategies and research questions.

To summarise, the summed probability distribution displays similar tendencies and the data demonstrate comparable patterns for the three sub-regions. The fluctuations in the summed probability distribution are small during the Mesolithic and no pronounced peaks or troughs can be seen, except at c. $7500 \mathrm{cal}$. BCE and $3900 \mathrm{cal}$. BCE. The curve is well within the $95 \%$ confidence interval of the variation in the simulated distributions and indicates a general stability in population sizes and settlement activity. The peak at 3800-3900 cal. BCE might be affected by dating strategies and research questions, an explanation that might also be relevant for the peak c. 7500 in the western part of the region as well, in addition to intensity in excavations. The effect of the calibration curve might also be a relevant factor. In general the summed probability distribution is rather stable during the Mesolithic and the Early and Middle Neolithic, before a sharp increase in dates can be seen from just before $2000 \mathrm{cal}$. BCE. The last peak is very distinct and crosses the upper limit of the $95 \%$ confidence interval.

\subsection{Shoreline dated Stone Age sites}

In order to further study the trend seen in the summed radiocarbon probability distributions and to investigate temporal variation in coastal settlement, we will here use site counts from three subareas (c.f. Fig. 4). In Fig. 6 we have compared the distribution of sites at different height a.s.l. in the investigated areas without correcting the height levels for variation in the shoreline displacement between areas. At a general level it is interesting to note that there are similarities in the overall distribution of sites. There are fewer sites at the highest levels, corresponding to the Early Mesolithic, with an increase towards lower levels, corresponding to the Middle and Late Mesolithic periods. When dated according to the different shoreline curves the distribution of surveyed sites show similar trends to the summed radiocarbon probability distribution (Fig. 7). Some variations can be seen and most noticeable is the reduction of sites between 7500 and 5500 cal. BCE. It can be several potential explanations for this pattern. The reduction might be caused by the flattening in the shoreline curves for the eastern and western parts of the region during this period, which is related to the mid-Holocene sea level rise (c.f. Fig. 2; c.f. Weninger et al., 2008). A flattening in the sea level curve during the Late Mesolithic could potentially lead to an increase in the number sites at the same heights, as it would be possible to settle along the same shorelines for longer time periods (see also Edinborough, 2005; 2009 for discussion of reduction of land mass and population fluctuation in Mesolithic Scandinavia). 
However, during this period it is argued for an increasing sedentary lifestyle in the region and in Southern Norway at large (Bergsvik, 2001; Glørstad, 2010), a trend that possibly started already in the Middle Mesolithic (Solheim and Persson, 2016; c.f. Boethius, 2017). Rather than seeing an increase in the actual number of sites, the same sites were used for longer periods due to decreasing mobility. An alternative explanation can be a potential bias in the site count data due to survey strategy or surveyed areas. Around $5000 \mathrm{cal}$. BCE there is an increase in number of sites followed by a gradual decrease during the Neolithic period. From c. 3000 cal. BCE there are few sites, which is reflecting changes in settlement and society at large with the establishment of agriculture. From this period the settlements were located away from the contemporary shoreline and farmsteads with long houses were established in areas with conditions favourable for farming (Prescott, 2012).

\subsection{Temporal variation in coastal demography and settlement: comparing radiocarbon dates and shoreline dated sites}

When we compare the summed radiocarbon probability distribution and the site count of shorelinedated sites a comparable pattern indicating temporal stability in coastal demography and settlement can be seen. The distribution of site counts do however indicate a more stable pattern with fewer peaks and troughs during the Mesolithic and Neolithic than what can be discerned in the summed radiocarbon probability distributions. This is likely a reflection of the temporal resolution of the site counts. An important conclusion can be drawn from this: From the transition to the Middle Mesolithic, c. 8300 cal. BCE until the Middle and Late Neolithic periods, c. 3000-2500 BCE, there was a stable settlement along the coast of the southeastern Norway, with no significant variations in settlement intensity. The relative reduction in sites noted between 7500 and $5500 \mathrm{cal}$. BCE is related to an increase in global sea levels and local equilibrium between land upheaval and sea level rise.

The marked drop in sites after 3000 cal. BCE is interpreted as linked to the establishment of agriculture as the dominant mean of subsistence and also a radical change in settlement systems with the establishment of agricultural settlement. The increase in C14-dates corresponds with the development of agrarian economy in the Late Neolithic and Early Bronze Age societies and the start of an increase in population size.

\section{Conclusion}

As no Holocene transgressions are identified in the Oslo fjord region there are unique possibilities to investigate long-term trends in coastal settlement during the early and mid-Holocene. The archaeological record is of high value for studying marine and coastal adaptations over long time spans. It is argued that the Preboreal pioneer settlement of Southern Norway was closely connected to marine resources for subsistence and to the coastal landscape for settlement and communication (Bang-Andersen, 2003; Bjerck, 2016; Breivik, 2014; Glørstad, 2013).

Our results show that the coastal area was of central importance for settlement and that it was able to sustain a stable population size during the Middle and Late Mesolithic as well as the first part of the Neolithic (see also Edinborough, 2009). The stability that is observed in the data might be a reflection of the abundance of resources. This is of importance for studies of Mesolithic population sizes in Europe as our observations contrast results from studies in other regions which tend to argue that Mesolithic population levels was low and fluctuated in response to climatic variation (Shennan and Edinborough, 2007; Riede,2009). Our results indicate that the demographic development might have been different in the coastal regions of northwestern Europe, and we consider the correspondence between the distributions of the two proxies to enhance the reliability of the general trends, and to strengthen the interpretation of a stable Mesolithic settlement (Fig. 7). 
In order to investigate the temporal variation in coastal demography and settlement we have applied and compared two different archaeological proxies: Summed radiocarbon probability distributions and site count data of shoreline-dated sites. Summed radiocarbon probability distributions is, as demonstrated in several other studies, a useful method for studying prehistoric demography (c.f. Edinborough et al., 2017:1). We have here tried to determine if the temporal distribution of radiocarbon dates from southeastern Norway present a reliable picture of intensity and variation in coastal settlement, and to present a clearly but general observable trend in the two proxies applied.

Both the summed radiocarbon probability distributions and site count data of shoreline-dated sites display similar patterns, and we have suggested that there was a stable settlement in the coastal areas of southeastern Norway between $8500 \mathrm{cal}$. BCE and $2400 \mathrm{cal}$. BCE. The similarities in the observed pattern in the distributions of the two proxy data strengthen our interpretation of a stable demographic development. The observations also suggest that there might have been some variations in settlement intensity during the period, with peaks starting at 7600-7500 and 3900-3800 cal. BCE. By comparing three different subareas we conclude that the radiocarbon data from southeastern Norway is relevant to use as proxy for variation in settlement and demography. Some of the peaks in the plot are possibly affected by archaeological activity in different sub-areas, but the marked increase in Late Neolithic is possible to identify in all three regions. The temporal distribution of shoreline-dated surveyed sites provides us with a general pattern of settlement intensity around the Oslo fjord. As for the summed radiocarbon distribution plot the site counts also exhibit an even distribution of sites during the Mesolithic and Neolithic. We suggest that the shoreline-dated sites further support the pattern observed in the summed probability distributions of radiocarbon dates. Hence, the general temporal distribution of radiocarbon data and shoreline-dated sites are demonstrating a stable and continuous settlement in the coastal areas of southeastern Norway during the early and mid-Holocene.

\section{Acknowledgements}

Thanks to our colleagues Hege Damlien, Guro Fossum, Herdis Hølleland and Karl-Gøran Sjögren for valuable comments. We would also like to thank the two not so anonymous reviewers for insightful and highly appreciated comments on the manuscript.

\section{References}

Apel, J., Wallin, P., Storå, J., Possnert, G., 2017. Early Holocene human population events on the island of Gotland in the Baltic Sea (9200-3800 cal. BP). Quat. Int. 2017 . http://dx.doi.org/10.1016/j.quaint.2017.03.044

Askeladden, 2015. https://askeladden.ra.no/Askeladden/Pages/LoginPage.aspx? ReturnUrl=\%2faskeladden (accessed june 2015).

Åstveit, L.I., 2014. Noen synspunkt på den tidligmesolittiske bosetningen i Sør-Norge. Primitive Tider 16, 87-104.

Bailey, G., 2011. Continental shelf archaeology: where next? In: Benjamin, J., Bonsall, C., Pickard, C., Fischer, A. (Eds.), Submerged Prehistory. Oxbow Books, Oxford, pp. $311-332$.

Bang-Andersen, S., 2003. Southwest Norway at the Pleistocene/Holocene transition: landscape development, colonization, site types, settlement patterns. Nor. Archaeol.Rev. 36 (1), 5-25. http://dx.doi.org/10.1080/00293650307293.

Bargel, T.H., Sørensen, R., 2005. Spor Etter Istiden i Oslo og Akershus. Gråsteinen, pp. 10.

Bergstrøm, B., 1999. Glacial geology, deglaciation chronology and sea-level changes in the southern Telemark and Vestfold counties, southeastern Norway. NGU Bulletin 435 (1999), 23-42.

Bergsvik, K.A., 2001. Sedentary and mobile hunterfishers in Stone Age Western Norway. Arct. Anthropol. 38 (1), 2-26 (DOI: http://www.jstor.org/stable/40316537).

Bevan, A., Colledge, S., Fuller, D., Fyfe, R., Shennan, S., Stevens, C., 2017. Holocene population, food production, and climate. In: Proceedings of the National Academy of Sciences Nov 2017pp. 201709190. http://dx.doi.org/10.1073/pnas.1709190114.

Bjerck, H.B., 2009. Colonizing seascapes: comparative perspectives on the development of maritime relations in Scandinavia and Patagonia. Arct. Anthropol. 46, 118-131. http://dx.doi.org/10.1353/arc.0.0019.

Bjerck, H.B., 2016. Settlements and seafaring: reflections on the integration of boats and settlements among marine foragers in early Mesolithic Norway and the Yámana of Tierra del Fuego. The Journal of Island and Coastal Archaeology 1-24. http://dx.doi.org/10.1080/15564894.2016.1190425. 
Boaz, J., 1998. Hunter-gatherer Site Variability. Changing Patterns of site Utilization in the Interior of Eastern Norway, Between 8000 and 2500 BP. Universitetets Oldsaksamlings Skrifter, Ny rekke. Nr. 20, Oslo.

Boethius, A., 2017. Signals of sedentism: faunal exploitation as evidence of a delayedreturn economy at Norje Sunnansund, an Early Mesolithic site in south-eastern Sweden. Quat. Sci. Rev. 2017, 1-24. http://dx.doi.org/10.1016/j.quascirev.2017.02.024.

Breivik, H., 2014. Palaeo-oceanographic development and human adaptive strategies in the Pleistocene-Holocene transition: a study from the Norwegian coast. The Holocene 1-13. http://dx.doi.org/10.1177/0959683614544061.

Breivik, H.M., Fossum, G., Solheim, S., 2017. Exploring human responses to climaticfluctuations and environmental diversity: two stories from Mesolithic Norway. Quat.Int. 1-18. http://dx.doi.org/10.1016/j.quaint.2016.12.019.

Crombé, P., Robinson, E., 2014. 14C dates as demographic proxies in Neolithisation models of northwestern Europe: a critical assessment using Belgium and northeast France as a case-study. J. Archaeol. Sci. 52, 558-566. http://dx.doi.org/10.1016/j.jas.2014.02.001.

Damlien, H., 2016. Between Tradition and Adaption-Long-Term Trajectories of Lithic Tool-Making in South Norway During the Postglacial Colonization and Its Aftermath (c. 9500-7500 cal. BC). PhD Thesis UiS no. 297 - August 2016. Museum of Archaeology, University of Stavanger.

Damlien, H., Solheim, S., 2017. The Pioneer Settlement of Eastern Norway. In: Blankholm, H.P. (Ed.), Early Economy and Settlement in Northern Europe - Pioneering, Resource Use, Coping with Change. Equinox eBooks Publishing, United Kingdom. http://dx.doi.org/10.1558/equinox.30736.

Edinborough, K., 2005. Evolution of Bow-arrow Technology. PhD thesis. University of London, London.

Edinborough, K., 2009. Population history and the evolution of mesolithic arrowhead technology in South Scandinavia. In: Shennan, S. (Ed.), Pattern and Process in Cultura Evolution. University of California Press, Berkeley, pp. 191-202.

Edinborough, K., Martindale, A., Cook, G.T., Supernant, K., Ames, K.M., 2016. A marine reservoir effect $\Delta$ R value for Kitandach, in Prince Rupert Harbour, British Columbia, Canada. Radiocarbon. http://dx.doi.org/10.1017/RDC.2016.46.

Edinborough, K., Porčić, M., Martindale, A., Brown, T.J., Supernant, K., Ames, K.M., 2017. Test of demographic events in written/oral history. In: Proceedings of the National Academy of Sciences Oct 2017, 201713012http://dx.doi.org/10.1073/pnas.1713012114.

Eigeland, L., 2015. Maskinmennesket i Steinalderen. Endring og Kontinuitet I Steinteknologi Fram mot Neolitiseringen av Øst-Norge. Thesis (PhD). Universitetet I Oslo.

Fossum, G., 2017. Hegna vest 1. En lokalitet med mellommesolittiske funnkonsentrasjoner og opphold i neolitikum, bronsealderen og eldre jernalder. In: Solheim, S. (Ed.), 2017 E18 Rugtvedt-Dørdal. Arkeologiske unders $ø$ kelser Av Lokaliteter Fra Steinalder Og Jernalder I Bamble Kommune, Telemark Fylke. Portal Forlag, Kristiansand, pp. $287-322$

French, J.F., Collins, C., 2015. Upper Palaeolithic population histories of Southwestern France: a comparison of the demographic signatures of $14 \mathrm{C}$ date distributions and archaeological site counts. J. Archaeol. Sci. 55, 122-134. http://dx.doi.org/10.1016/j.jas.2015.01.001.

Glørstad, H. (Ed.), 2004. Svinesundprosjektet. Bind 4, Oppsummering av Svinesundprosjektet. UKM Varia 57. Universitetets kulturhistoriske Museer,Oldsaksamlingen, Oslo.

Glørstad, H., 2010. The Structure and History of the Late Mesolithic Societies in the Oslo Fjord Area 6300-3800 BC. Bricoleur Press, Mölndal.

Glørstad, H., 2013. Where are the missing boats? The pioneer settlement of Norway as long-term history. Nor. Archaeol. Rev. http://dx.doi.org/10.1080/00293652.2013.777095.

Glørstad, H., 2016. Deglaciation, sea-level change and the Holocene colonization ofNorway. In: Harff, J., Bailley, G., Lüth, F. (Eds.), Geology and Archaeology: Submerged Landscapes of the Continental Shelf. London: Geological Society, pp. 1-17. Special Publications 411. https://doi.org/10.1144/SP411.7.

Hafsten, U., 1956. Pollen-analytic investigations on the Late Quaternary development in the inner Oslofjord area. In: Universitetet i Bergen Årbok. MatematiskNaturvitenskapelig Serie 8 (1956).

Hinz, M., Fesser, I., Sjögren, K.-G., Müller, J., 2012. Demography and the intensity of cultural activities: an evaluation of Funnel Beaker Societies (4200-2800 cal. BC) J.Archaeol. Sci. 39, 3331-3340. http://dx.doi.org/10.1016/j.jas.2012.05.028

Jaksland, L., 2001. Vinterbrolokalitetene - en Kronologisk Sekvens fra Mellom- og Senmesolitikum i Ås, Akershus. Varia 52. Universitetets kulturhistoriske museer,Oldsaksamlingen, Oslo.

Jaksland, L., 2014. Kulturhistorisk sammenstilling. In: Jaksland, L., Persson, P. (Eds.), E18 Brunlanesprosjeketet Bind I. Forutsetninger Og Kulturhistorisk Sammenstilling. Varia 79. Museum of Cultural History, University of Oslo, Oslo, pp. 11-62.

Jaksland, L., Persson, P. (Eds.), 2014. E18 Brunlanesprosjeketet Bind I. Forutsetninger Og Kulturhistorisk Sammenstilling. Varia 79. Museum of Cultural History, University of Oslo.

Lindblom, I., 1984. Former for Økologisk Tilpasning i Mesolitikum, Østfold. Universitetets Oldsaksamling Årbok, 1982/1983. pp. 43-86.

Melvold, S.A., Persson, P. (Eds.), 2014. Tidlig- Og Mellommesolittiske Lokaliteter I Vestfold Og Telemark. Vestfoldbaneprosjektet, Bind 1. Portal forlag, Kristiansand.

Michczyñski, A., Michczyñska, D.J., 2006. The effect of PDF peaks' height increase during calibration of radiocarbon date sets. Geochronometria 25, 1-4

Mikkelsen, E., 1978. Seasonality and mesolithic adaption in Norway. In: Kristiansen, K.,Paludan-Müller, C. (Eds.), New Directions in Scandinavan Archaeology, Studies inScandinavian Prehistory and Early History. Vol. 1. The National museum of Denmark, Copenhagen, pp. 79-119.

Olsen, M., 2012. Arkeologisk Registrering E18 Rugtvedt-Dørdal. (Rapport. Telemark fylkeskommune).

Palmisano, A., Bevan, A., Shennan, S., 2017. Comparing archaeological proxies for longterm population patterns: an example from central Italy. J. Archaeol. Sci. 87, 59-72. http://dx.doi.org/10.1016/j.jas.2017.10.001

Påsse, T., 2003. Strandlinjeförskjutning i norra Bohuslän under holocen. In: Persson, P. (Ed.), Strandlinjer Och Vegetationshistoria. Kvartärgeologiska undersökningar Inom Kust till Kust Projektet, 1998-2002. Arkeologiskt Naturvetenskapliga Laboratoriet, Göteborg, pp. 31-87. 
Persson, P., 2014. Registrering av stenålderslokaler inför Vestfoldbaneprosjektet. In Melvold, S., Persson, P. (Eds.), 2014. Vestfoldbaneprosjektet. Arkeologiske Unders $ø$ kelser i Forbindelse Med ny Jernbane Mellom Larvik og Porsgrunn. Bind 1, Tidlig- og Mellommesolittiske Lokaliteter i Vestfold og Telemark. Portal forlag, Kristiansand, pp. 55-57.

Petterson, M., Wikell, R., 2014. Where sky and sea are one. Close encounters with early seafarers and seal-hunters off the Swedish Baltic coast. In: Riede, F., Tallaavaara, M.(Eds.), Lateglacial and Postglacial Pioneers in Northern Europe. BAR International Series 2599pp. 103-119.

Prescott, C., 2012. Third millennium transformation in Norway: modelling an interpretative platform. In: Prescott, C., Glørstad, H. (Eds.), Becoming European. The Transformation of Third Millennium Northern and Western Europe. Oxbow books, Oxford, pp. 115-127.

Reimer, P., Bard, E., Bayliss, A., Beck, J., Blackwell, P., Ramsey, C., Buck, C.E., Cheng, H.,Edwards, R.L., Friedrich, M., Grootes, P.M., Guilderson, T.P., Haflidason, H., Hajdas, I., Hatté, C., Heaton, T.K., Hoffmann, D.L., Hogg, A.G., Hughen, K.A., Kaiser, F.K., Kromer, B., Manning, S.W., Niu, M., Reimer, R.W., Richards, D.A., Scott, M.E., Southon, J.R., Staff, R.A., Turney, C.S.M., Van der Plicht, J., 2013. IntCal13 and Marine13 radiocarbon age calibration curves 0-50,000 years cal BP. Radiocarbon 55(4), 1869-1887. http://dx.doi.org/10.2458/azu_js_rc.55.16947.

Reitan, G., 2016. Mesolittisk kronologi i Sørøst-Norge - et forslag til justering. Viking 79, 23-52.

Reitan, G., Persson, P., 2014. Vestfoldbaneprosjektet. Arkeologiske Undersøkelser i Forbindelse Med ny Jernbane Mellom Larvik og Porsgrunn Kommune. Bind 1,Seinmesolittiske, Neolittiske og Yngre Lokaliteter i Vestfold og Telemark. Portal forlag, Kristiansand (eds.)

Riede, F., 2009. Climate and demography in early prehistory: using calibrated $14 \mathrm{C}$ dates as population proxies. Hum. Biol. 81, 309-337. http://dx.doi.org/10.1353/hub.0.0051.

Schmitt, L., Larsson, S., Schrum, C., Alekseva, I., Tomczak og, M., Svedhage, K., 2006. Why they came': The colonization of the coast of western Sweden and its environmental context at the end of last glaciation. Oxf. J. Archaeol. 25 (1), 1-28

Shennan, S., Downey, S.S., Timpson, A., Edinborough, K., Colledge, S., Kerig, T. Manning, K., Thomas, M.G., 2013. Regional population collapse followed initialagriculture booms in mid-Holocene Europe. Nat. Commun. 4, 2486. http://dx.doi.org/10.1038/ncomms3486.

Shennan, S., Edinborough, K. 2007. Prehistoric population history: from the Late Glacialto the Late Neolithic in central and northern Europe. J. Archaeol. Sci. 34, 13391345.http://dx.doi.org/10.1016/j.jas.2006.10.031.

Solheim, S., 2013. Naturvitenskapelige analyser. In: Solheim, S., Damlien, H. (Eds.), E18Bommestad-Sky. Undersøkelser Av Lokaliteter Fra Mellommesolitikum, Larvik Kommune, Vestfold Fylke. Portal forlag, Kristiansand, pp. 42-48.

Solheim, S. (Ed.), 2017. E18 Rugtvedt-Dørdal. Arkeologiske undersøkelser Av Lokaliteter Fra Steinalder Og Jernalder I Bamble Kommune, Telemark fylke. Portal forlag,Kristiansand.

Solheim, S., 2017a. Introduksjon til undersøkte lokaliteter og området. In: Solheim, S. (Ed.), 2017. E18 Rugtvedt-Dørdal. Arkeologiske Undersøkelser Av Lokaliteter FraSteinalder Og Jernalder I Bamble Kommune, Telemark Fylke. Portal forlag, Kristiansand, pp. 97-102.

Solheim, S., 2017b. Naturvitenskap og andre ekspertanalyser. In: Solheim, S. (Ed.), 2017. E18 Rugtvedt-Dørdal. Arkeologiske Undersøkelser Av Lokaliteter Fra Steinalder Og Jernalder I Bamble Kommune, Telemark Fylke. Portal forlag, Kristiansand, pp. 63-76.

Solheim, S., 2017c. Kunnskapsstatus og faglig bakgrunn for undersøkelsene. In: Solheim, S. (Ed.), 2017. E18 Rugtvedt-Dørdal. Arkeologiske undersøkelser Av Lokaliteter Fra Steinalder Og Jernalder I Bamble Kommune, Telemark Fylke. Portal forlag, Kristiansand, pp. 29-43.

Solheim, S., Damlien, H. (Eds.), 2013. E18 Bommestad-Sky. Undersøkelser Av Lokaliteter Fra Mellommesolitikum, Larvik Kommune, Vestfold Fylke. Portal forlag, Kristiansand.

Solheim, S., Olsen, D.E.F., 2013. Hovland 3. Mellommesolittisk boplass med hyttetuft. In: Solheim, S., Damlien, H. (Eds.), E18 Bommestad-Sky. Undersøkelser Av Lokaliteter Fra Mellommesolitikum, Larvik Kommune, Vestfold Fylke. Portal forlag, Kristiansand, pp. 198-235.

Solheim, S., Persson, P., 2016. Marine adaptation in the Middle Mesolithic of southeastern Norway. In: Bjerck, H.B., Breivik, H.M., Fretheim, S.E., Piana, E.L., Skar, B., Tivoli, A.M., Zangrando, F.J. (Eds.), Marine Ventures. Archaeological Perspectives on Human-Sea Relations. Equinox, Bristol, pp. 261-276.

Sørensen, R., 1979. Late Wechselian deglaciation in the Oslofjord area. Boreas 8,241-246.

Sørensen, R., 1999. En 14C datert og dendrokronologisk kalibrert strandforskyvningskurve for søndre Østfold. In: Selsing, L., Lillehammer, G. (Eds.), Museumslandskap. Artikkelsamling Til Kerstin Griffin på 60-årsdagen. AmS-Rapport 12, Bind A. Arkeologisk museum i Stavanger, Stavanger, pp. 59-70.

Sørensen, R., Henningsmoen, K., Høeg, H.I., Gälman, V., 2014a. Utviklingen av det senglasiale og tidlig preboreale landskapet og vegeasjonen omkring steinalderboplassene ved Pauler. In: Jaksland, L., Persson, P. (Eds.), E18 Brunlanesprosjektet. Bind 1, Forutsetninger Og Kulturhistorisk Sammenstilling. KHM Varia 79. Kulturhistorisk museum, Universitetet i Oslo, Oslo, pp. 171-218.

Sørensen, R., Henningsmoen, K., Høeg, H.I., Gälman, V., 2014b. Holocene landhevningsstudier i søndre Vestfold og sørsøstre Telemark - revidert kurve. In: Melvold, S., Persson, P. (Eds.), Vestfoldbaneprosjektet. Arkeologiske unders $ø$ kelser I Forbindelse Med Ny Jernbane Mellom Larvik Og Porsgrunn Kommune. Bind 1, Tidlig-Og Mellommesolittiske Lokaliteter I Vestfold Og Telemark. Portal forlag, Kristiansand, pp. 236-247.

Sørensen, R., Høeg, H.I., Gälman, V., 2015. Revidert Strandlinjeforskyvningskurve for Bamble. Report for the Project E18 Rugtvedt-Dørdal. Kulturhistorisk Museum.

Surovell, T., Brantingham, P.J., 2007. A note on the use of temporal frequency distributions in studies of prehistoric demography. J. Archaeol. Sci. 34, 18681877.http://dx.doi.org/10.1016/j.jas.2007.01.003

Tallavaara, M., Pesonen, P., Oinonen, M., 2010. Prehistoric population history in eastern Fennoscandia. J. Archaeol. Sci. 37, 251-260. http://dx.doi.org/10.1016/j.jas.2009.09.035.

Théry-Parisot, I., Chabal, L., Chrzavzez, J., 2010. Anthracology and taphonomy, from wood gathering to charcoal analysis. A review of the taphonomic processes modifying charcoal assemblages, in archaeological contexts. Palaeogeogr. Palaeoclimatol. Palaeoecol. 291, 142-153. http://dx.doi.org/10.1016/j.palaeo.2009.09.01.

Timpson, A., Colledge, S., Crema, E., Edinborough, K., Kerig, T., Manning, K., Thomas, M.G., Shennan, S., 2014. Reconstructing regional population fluctuations in the European Neolithic using radiocarbon dates: a new case-study using an improved method. J. Archaeol. Sci. 52, 549-557. http://dx.doi.org/10.1016/j.jas.2014.08.011.

Timpson, A., Manning, K., Shennan, S., 2015. Inferential mistakes in population proxies: a response to Torfing's "Neolithic population and summed probability distribution of 14C-dates". J. Archaeol. Sci. 63, 199-202. https://doi.org/10.1016/j.jas.2015.08.018 
Torfing, T., 2015. Neolithic population and summed probability distribution of 14C-dates. J. Archaeol. Sci. 63, 193-198. http://dx.doi.org/10.1016/j.jas.2015.06.004.

Weninger, B., Schulting, R., Bradtmöller, M., Clare, L., Collard, M., Edinborough, K.,Hilpert, J., Jöris, O., Niekus, M., Rohling, E.J., Wagner, B., 2008. The catastrophic final flooding of Doggerland by the Storegga Slide tsunami. Documenta Praehistorica 35, 1-24.

Wicks, K., Mithen, S., 2014. The impact of the abrupt 8.2 ka cold event on the Mesolithic population of western Scotland: a Bayesian chronological analysis using "activity events" as a population proxy. J. Archaeol. Sci. 45, 240-269. http://dx.doi.org/10.1016/j.jas.2014.02.003.

Williams, A.N., 2012. The use of summed radiocarbon probability distributions in archaeology: a review of methods. J. Archaeol. Sci. 39, 578-589. http://dx.doi.org/10.1016/j.jas.2011.07.014. 


\section{Figures:}
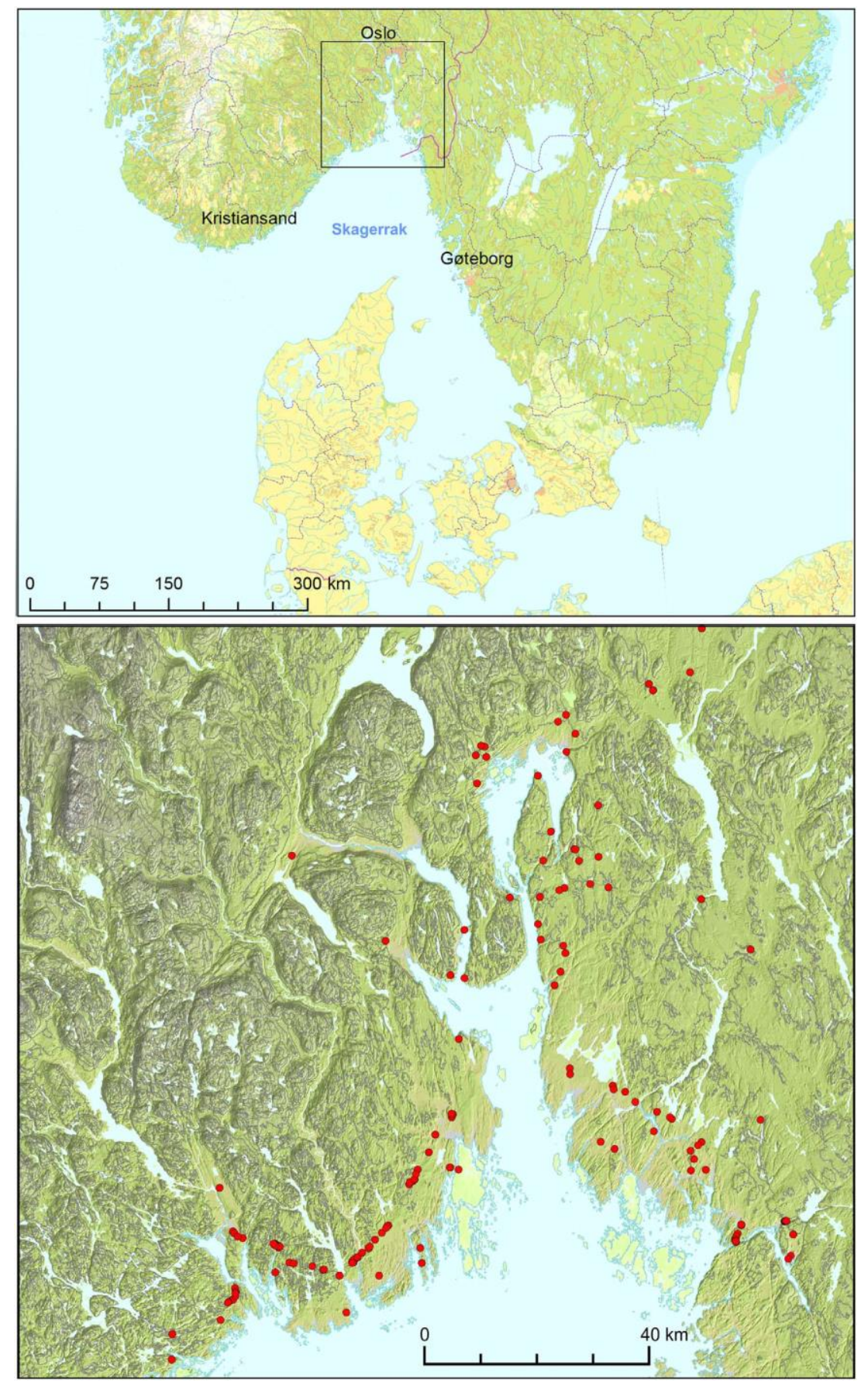

Fig. 1. The location of the South-eastern Norway. The detailed map below show all sites with radiocarbon dates older than $3000 \mathrm{BP}$, which is included in this analysis. 


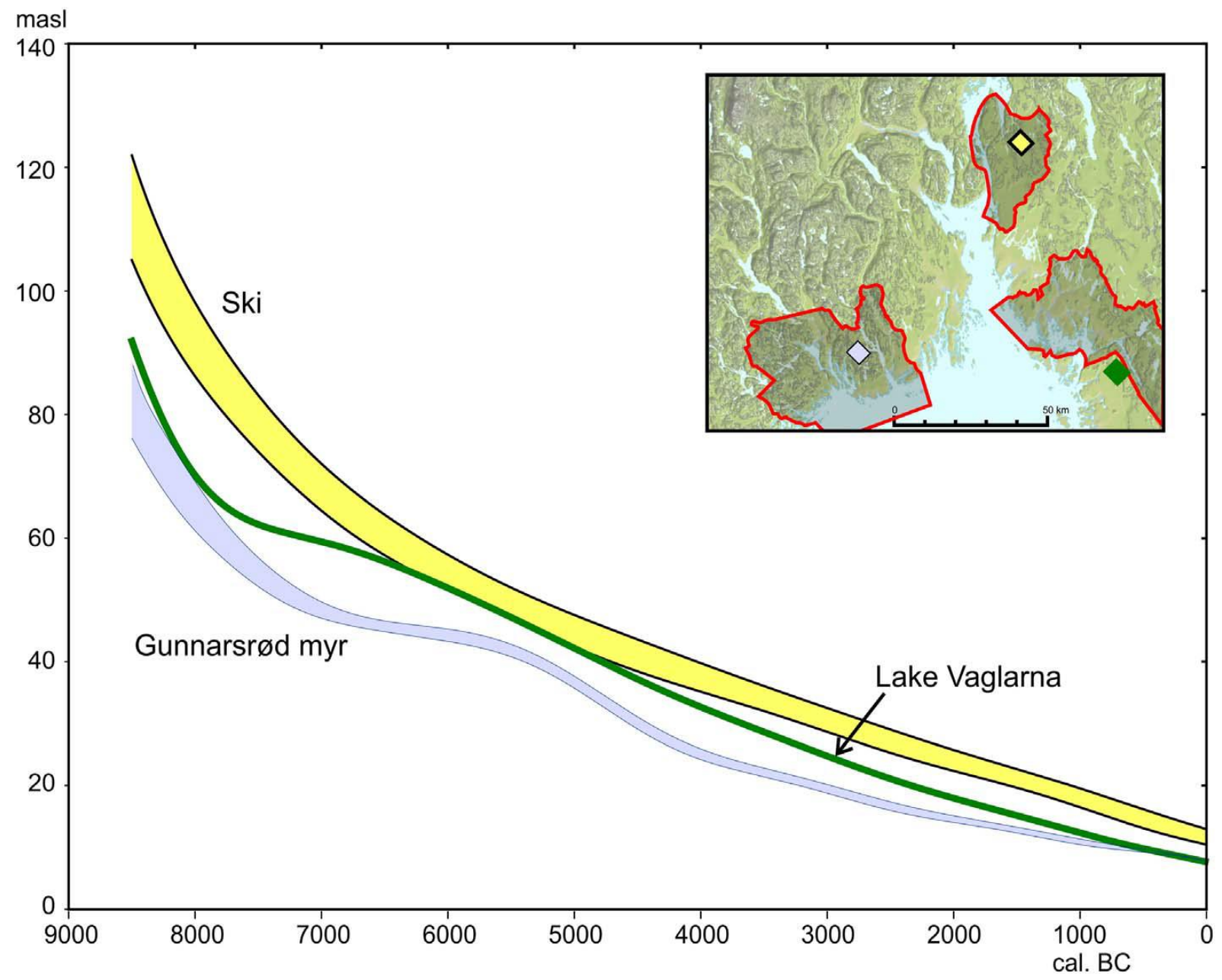

Fig. 2. The different shoreline displacement curves, which are used in this analysis. The map in the top right corner refers the location of the three subareas discussed in the paper (c.f. Fig. 5) and to the geographical location of the shoreline displacement curves. The colour of the symbol corresponds with the colour of the curve. The curve from Gunnarsrød myr is from Sørensen et al. 2012, Lake Vaglarna from Påsse, 2003, and Ski from Bargel and Sørensen, 2005. 


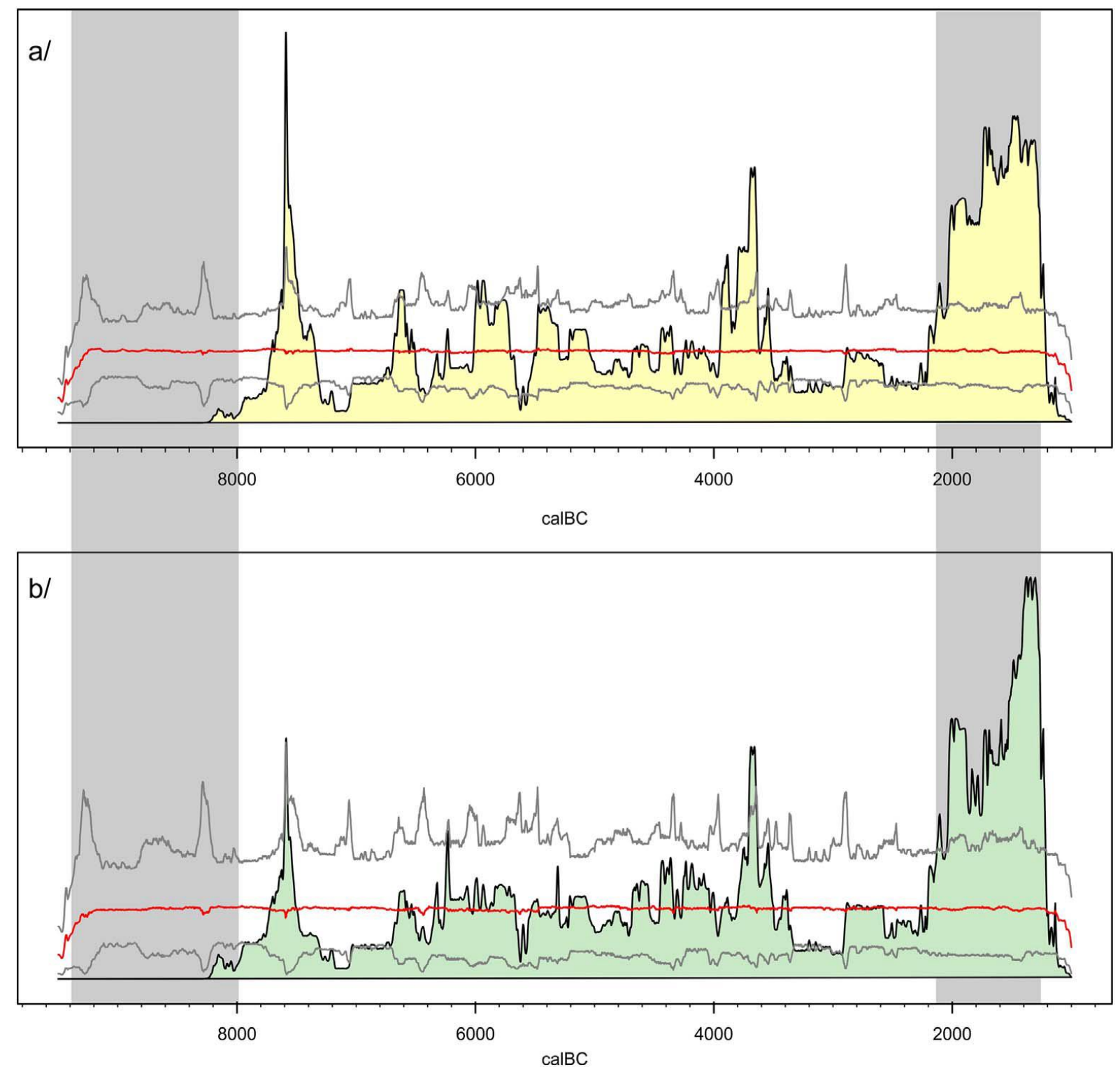

Fig. 3. a/: Curve with yellow fill shows calibrated summed probability density (SPD) for all radiocarbon dates $>3000$ bp uncalibrated from archaeological sites around the Oslofjord, 512 dates from the 157 sites in Fig. 1. Grey lines=upper and lower limits for $95 \%$ confidence interval and red line=median for 1000 simulations of 512 dates. The simulation assumes constant settlement from 9500 to 1000 cal. BCE. In each simulation round 512 years are randomly picked in the interval, they are back-calibrated and each of them combined with the standard deviations from actual 512 dates. Theses series of 512 simulated radiocarbon dates are calibrated. This is repeated 1000 times. From the 1000 simulated SPDs the median and the $95 \%$ confidence interval are calculated for each year. b/: The same dates but using "binning" so that radiocarbon dates from a site that are $<200$ radiocarbon years apart are combined. This account for oversampling, and sites with different amount of dates were equally weighted in the analysis. This gives 263 phases (=dates), that are compared with simulated series of 263 dates as described under "a". Grey background marks periods with significant deviation from the assumption of constant population. 


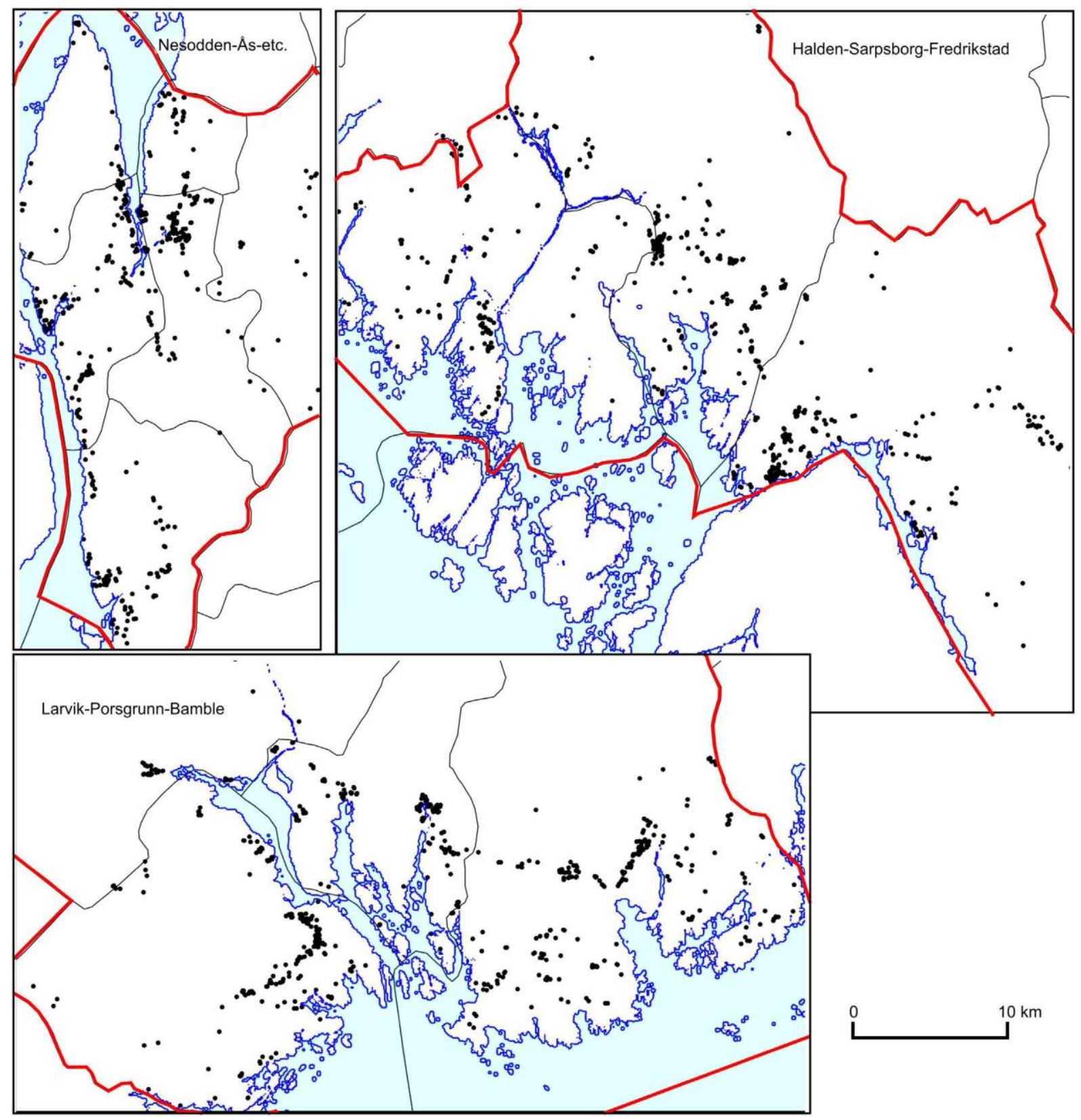

Fig. 4. The maps show the surveyed sites $(n=1709)$ in three investigated sub-areas. The positions of the three areas are shown in Fig. 2. The red lines marks the boundary of the administrative districts included in this investigation. Each dot on the map corresponds to one site in the Directorate of Cultural Heritage's national database of archaeological sites. 


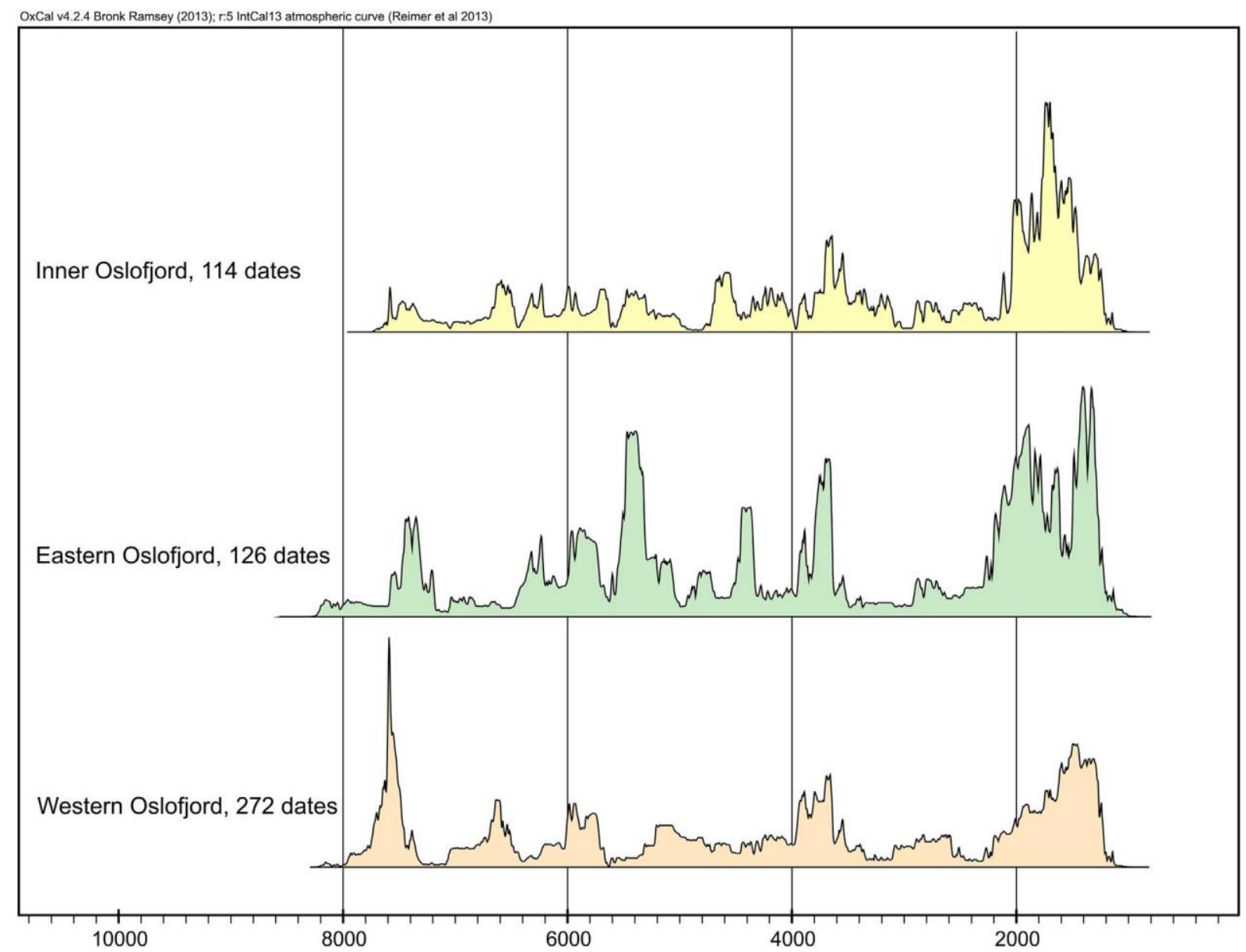

Fig. 5. Radiocarbon dates from SE Norway divided into the three subareas, equivalent to the areas in Figs. 2 and 5. The dates are calibrated with OxCal sum function (v. 4.3). The maximum heights for all three curves are the same. 


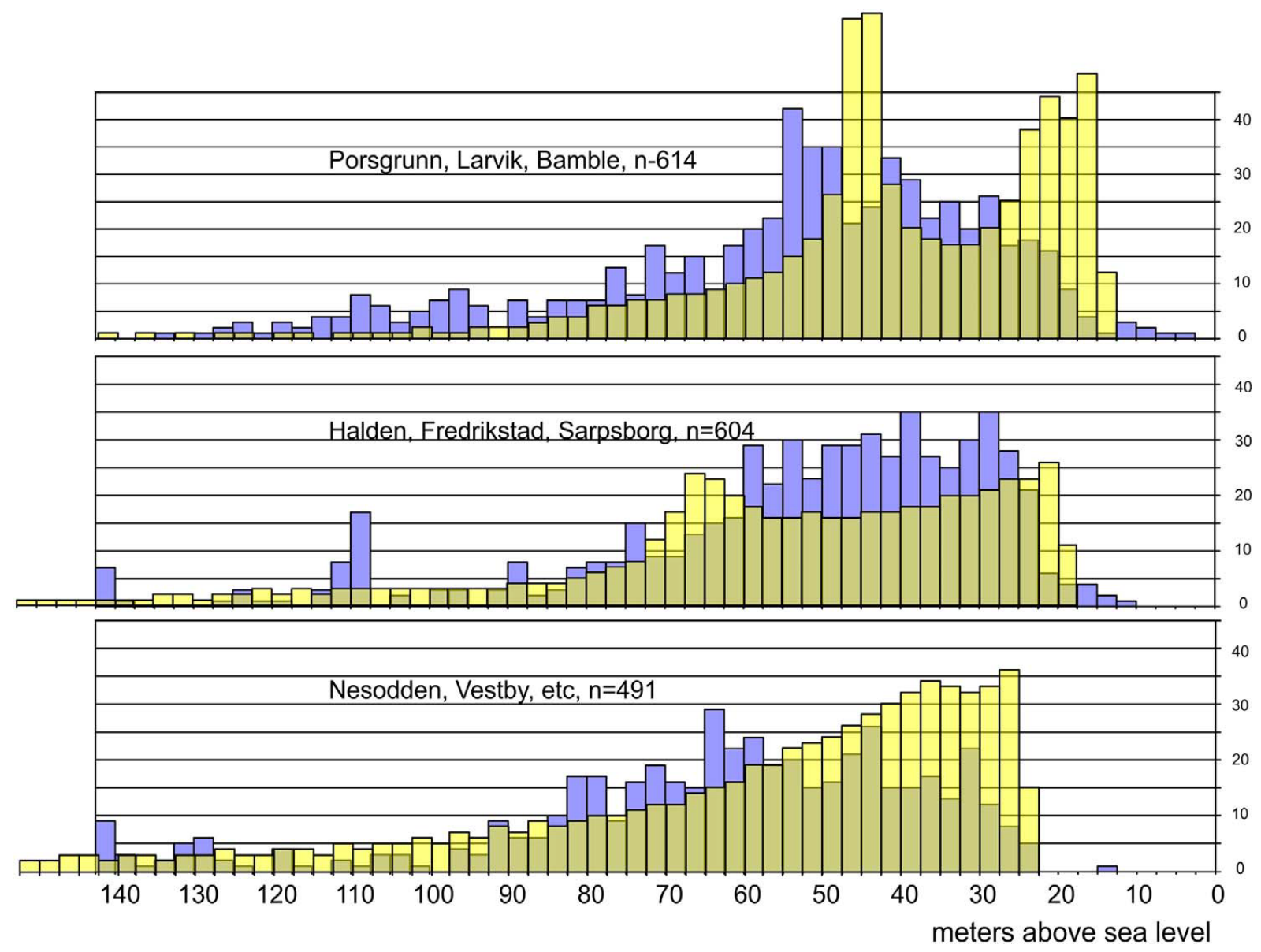

Fig. 6. Surveyed sites in the three investigated subareas, distributed according to the sites' height above present sea level. A) Western part of the region, $n=614$ sites. B) Eastern part of the region, $n=604$ sites. C) Inner part of the region, $n=491$ sites. The actual distribution of sites per height interval is shown in the blue bars, while the yellow bars shows the same number of sites modelled as they would have been distributed if the all been situated directly on the shore according to the local shore displacement curves (i.e.proportional to year/one meter of the displacement curve). (

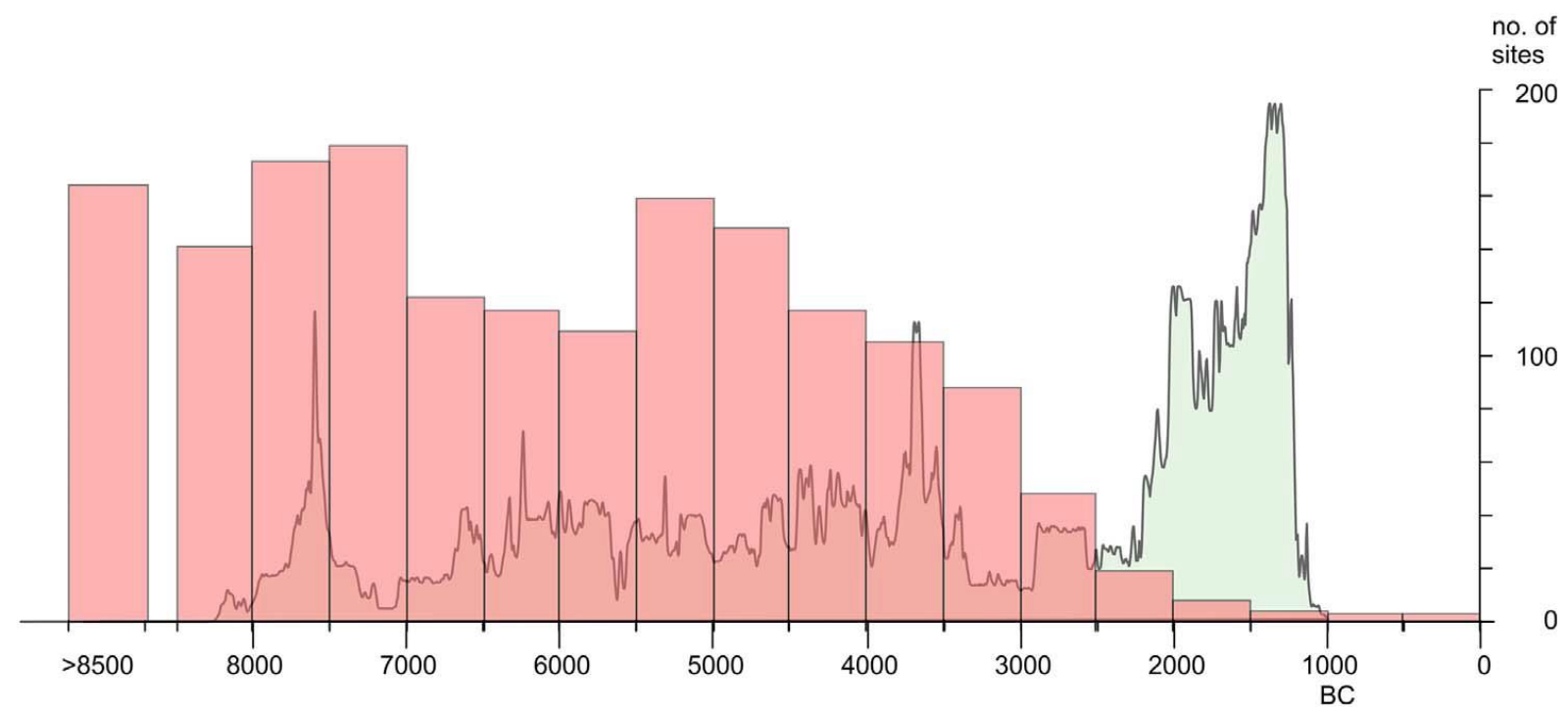


Fig. 7. The red bars represent the shoreline dating of surveyed sites, c.f. Fig. 6. In the background is the summed probability distribution of radiocarbon date bins from South-eastern Norway (c.f. Fig. 3b). The two data sets display a similar trend with stable settlement during the Mesolithic and early part of the Neolithic. 